\title{
1. Key Melanesian media freedom challenges Climate crisis, internet freedoms, fake news and West Papua
}

\begin{abstract}
Melanesia, and the microstates of the Pacific generally, face the growing influence of authoritarian and secretive values in the region - projected by both China and Indonesia and with behind-the-scenes manipulation. There is also a growing tendency for Pacific governments to use unconstitutional, bureaucratic or legal tools to silence media and questioning journalists. Frequent threats of closing Facebook and other social media platforms and curbs on online freedom of information are another issue. While Pacific news media face these challenges, their support networks are being shaken by the decline of Australia as a so-called 'liberal democracy' and through the undermining of its traditional region-wide public interest media values with the axing of Radio Australia and Australia Network television. Reporting climate change is the Pacific's most critical challenge while Australian intransigence over the issue is subverting the region's media. This article engages with and examines these challenges and also concludes that the case of West Papua is a vitally important selfdetermination issue that left unresolved threatens the security of the region.
\end{abstract}

Keywords: climate change, climate crisis, corruption, China, fake news, Indonesia, internet, media freedom, Melanesia, West Papua

\section{DAVID ROBIE \\ Pacific Media Centre, Auckland University of Technology}

T NEVER ceases to amaze me how politicians in the Pacific manage to regularly shoot themselves in the foot over media freedom. Many simply fail to recognise the importance of news media in democracy, development and policy making. They just do not want to be questioned or challenged.

On the eve of the Melanesia Media Freedom Forum (MMFF), which was organised at Griffith University in November 2019, there were three major assaults on media freedom. Ironically, these happened at the very moment that the MMFF was about to 'respond to increasing media repression in Melanesia and to future-proof press freedom through transnational regional cooperation 


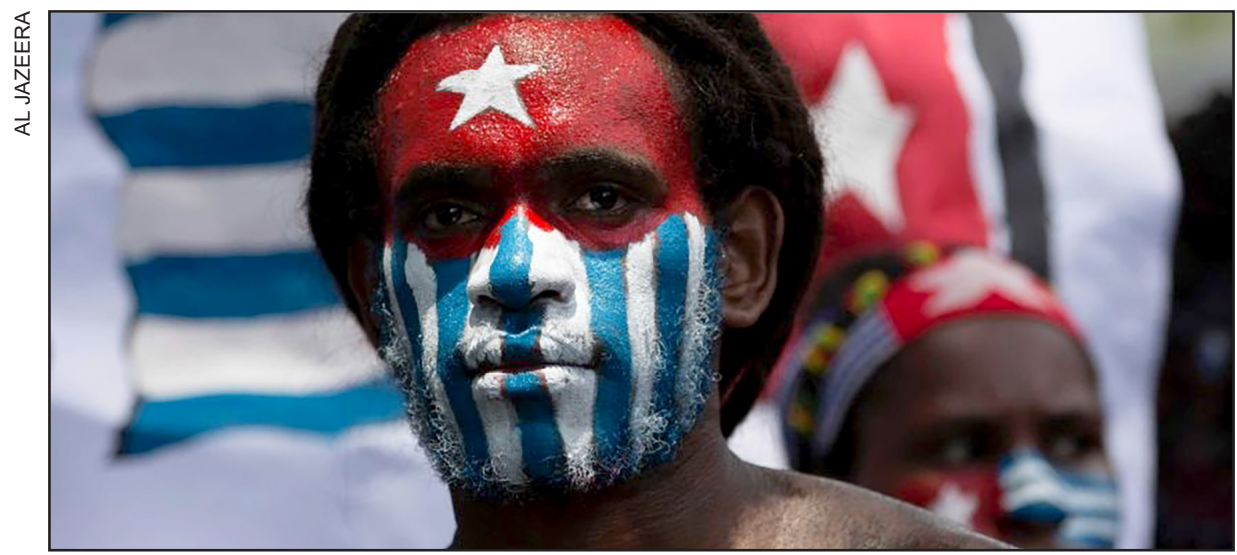

Figure 1: Melanesia Media Freedom Forum (MMFF): Addressing Increasing media repression in Melanesia, such as in West Papua.

and knowledge-sharing' (MMFF, 2019) among journalists, editors, publishers, press freedom advocates and journalism scholars (Figure 1).

\section{Growing authoritarianism and legal gags}

First, on 6 November 2019, just days before journalists, editors, publishers, press freedom advocates and journalism scholars gathered to debate press freedom, the Premier of Western Province in the Solomon islands, David Gina, threatened to close down the local office of Island Sun in the provincial capital of Gizo because of a series of embarrassing exposés in the newspaper (Nantara, 2019). 'I am working hard to make this province great again and all I get from your paper is articles rubbishing my reign and regime,' he declared. 'I will not tolerate opposition inside my province.'

Two days later, on November 8, the media director of the Vanuatu Daily Post, Dan McGarry, revealed on his Facebook page the disturbing news that he had been denied a renewal of his work permit (Davidson, 2019; McGarry, 2019b). The lame official excuse was apparently that he had not 'localised' his position by then.

Although McGarry is Canadian, he has lived in Vanuatu for 16 years, his wife and two daughters are ni-Vanuatu and had applied for Vanuatu citizenship.

The Vanuatu government's reaction was quite outrageous. Dan McGarry is one of the leading investigative journalists and editors in the Pacific, and a courageous inspiration to all. McGarry has also been a strong media freedom advocate and has followed the proud traditions set by the Daily Post's founder and owner, Marc Neil-Jones, by publishing the truth and holding the powerful to account. His short, crisp and challenging Facebook statement said:

After over a month of delay and uncertainty, I was informed this afternoon that my work permit has been rejected. 
The overt reason is that my position should have been localised by now. But we all know the real reason: The Daily Post reporting on the government's activities has raised such discomfort that they are willing to abuse administrative processes to silence me.

In July, the Prime Minister summoned me and berated me for my 'negative' reporting. 'If you don't like it here,' he told me, 'go home'.

But Vanuatu is my home.

Everything and everyone I love is here. I have devoted 16 years of my life to this country's development. I took the job of Media Director because I knew the country needed someone who was willing to step into the Daily Post founder Marc Neil-Jones' shoes.

I have spent all my years here in service to this country. I love Vanuatu. I can't imagine a life without it.

And now, I'm being told I have no place here. Because I spoke out for the truth, and the rule of law.

People will hem and haw and say all kinds of things, but it all boils down to this: I spoke out and was punished for telling the truth. (McGarry, 2019b)

Media freedom groups condemned this draconian action by the Vanuatu government and social media postings ran hot with allegations by some correspondents that Chinese influence was behind it. McGarry said he was 'gutted' by the action and declared he would 'fight for justice' (Krishnamurthi, 2019). One correspondent claimed that the work refusal was because of an article published in July highlighting 'the depths to which China pressures Vanuatu and how deeply Vanuatu bends to China' (McGarry, 2019c).

This claim was shared by others and echoed in The Guardian on November 8 when the newspaper reported that in July the Daily Post had '[broken] the story of Vanuatu deporting six Chinese nationals - four of whom had obtained Vanuatu citizenship without due process of access to legal counsel' (Davidson, 2019). McGarry began his July 8 article with this introduction:

Under a veil of secrecy, China has convinced Vanuatu to enforce Chinese law within its own borders.

Six Chinese nationals were arrested, detained without charge on the premises of a Chinese company with numerous large government contracts. Without access to the Vanuatu courts, they were escorted out of Vanuatu with Chinese police holding one arm and Vanuatu Police holding the other.

Neither Chinese nor Vanuatu police were in uniform. (McGarry, 2019a)

The third media freedom issue on the eve of the Melanesia Forum was a controversy over an Australian-based 60 Minutes crew, including Nine Network 
journalist Liam Bartlett, which was detained 'under house arrest' by Kiribati authorities at their hotel before being deported on October 31 for allegedly violating conditions after failing to apply for a filming permit before arriving in the country (Lyons \& Meade, 2019). A spokesperson claimed the crew 'intentionally came to Kiribati without applying for a permit' and then 'lied about the reason for their visit' to Immigration officials at Tarawa airport (Wasuka, 2019). The 60 Minutes crew were researching a story about Kiribati's decision to sever diplomatic ties with Taiwan in favour of China.

This raises some of the key geopolitical media issues facing Melanesia (and the Pacific) at present (Figure 2):

1. The growing influence of authoritarian and secretive values in the region-projected by both China and Indonesia with behind-the-scenes manipulation;

2. A growing tendency for Pacific governments to use unconstitutional, bureaucratic or legal tools to silence media and questioning journalists;

3. Frequent threats to close Facebook and other social media platforms and curbs on online freedom of information;

4. The decline of Australia as a so-called 'liberal democracy' and the undermining of its traditional region-wide public interest media values with the axing of Radio Australia and Television Australia;

5. Reporting climate change as the Pacific's most critical challenge while Australian intransigence over the issue is subverting the region's media; and

6. The case of West Papua, a vitally important self-determination issue which, left unresolved, threatens the security of the region.

\section{Facebook and social media threats}

As this article has already raised the first two concerns - both issues being compounded because of a cultural 'big man' syndrome whereby many Pacific journalists are reluctant to ask the hard questions of political leaders and those in high office - the third challenge will now be addressed.

Social media has been a healthy antidote to growing cultures of self-censorship in the Pacific, particularly in Fiji and Papua New Guinea, with Melanesian journalists increasingly using online blogs as 'safety valve' journalism-an outlet for hidden truths. Kudos to journalists such as EMTV's Scott Waide for setting positive examples. However, governments in the region are increasingly using authoritarian methods to shut down, or gag social media. The attempts to gag Waide during Asia-Pacific Economic Cooperation (APEC) in November 2018 and other EMTV staff more recently by government interference in their company were outrageous (PMW, 2019a). 


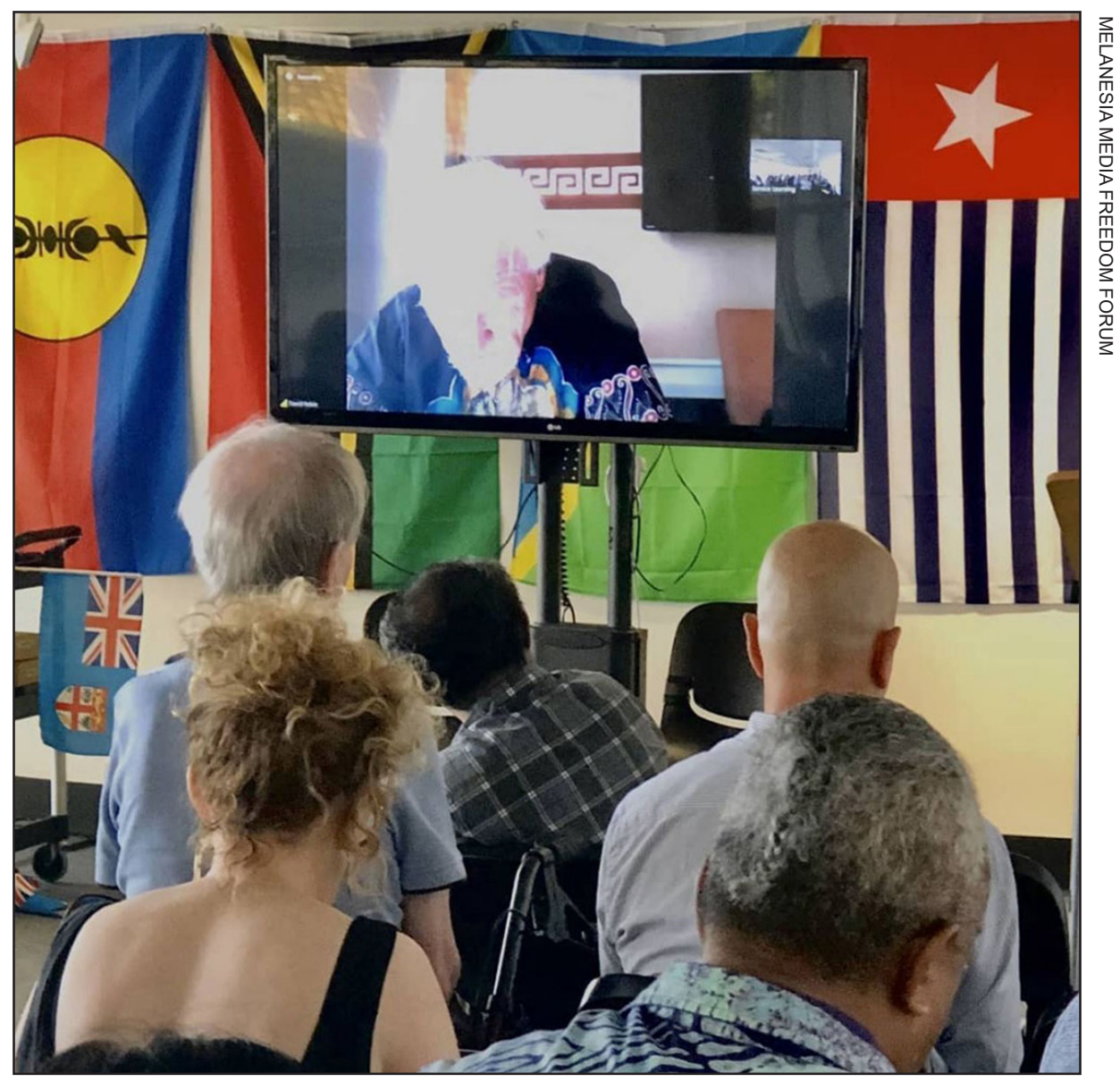

Figure 2: David Robie raising geopolitical issues by Zoom from Yogyakarta, Indonesia, at MMFF on 12 November 2019.

Jope Tarai of Fiji has done some ground-breaking research on how the incumbent Fiji government manipulated both the 2014 and 2018 general elections, published in the last edition of Pacific Journalism Review (Tarai, 2019). Also, recent research in Pakistan has shown that Fiji is not alone. In countries such as India, Indonesia, Philippines and Sri Lanka, where there are long-standing ethnic and religious tensions, citizens are relying on online information in significant numbers (Raza, 2019). Fake news, disinformation and media manipulation are now critical issues. There are lessons for Melanesia and the Pacific.

\section{Australia's waning Pacific influence}

Australia's waning influence and arrogance towards the Pacific was of special interest given that the MMFF symposium was in Brisbane. In October 2019, human rights lawyer Jennifer Robinson, who has played a key role in defending 
West Papuan political prisoners, penned an op-ed article in The Sydney Morning Herald, which questioned Australia's right to continue being called a liberal democracy (Robinson, 2019). She wrote:

Between police raids on journalists, unlawful accessing of metadata to identifying a journalist's source, and a spree of new national security legislation which criminalises journalistic activity, the recent actions of the Australian government sound less like those of a liberal democracy than of an authoritarian regime.

This is dangerous, not just for Australian journalists, but for journalists everywhere. (Robinson, 2019)

Robinson cited how fellow human rights lawyer Amal Clooney had warned in a World Media Freedom conference in London in July that whatever happened in Australia 'will be looked at by every other leader in the world and potentially used as an excuse to clamp down even further on journalists' (Clooney, 2019). At the London conference, Clooney also raised free speech concerns about the United States indictment for Australian activist publisher Julian Assange. He was in jail in the United Kingdom facing US extradition and 175 years in prison for the same WikiLeaks publications which won him the 2011 Walkley Award for Most Outstanding Contribution to Journalism.

Robinson wrote that there was no denying the parallels between the 2019 Australian Police Force raids on journalists and the Assange indictment. Sadly, Australia is no longer the bastion of media freedom that Melanesia and the Pacific generally have looked to as a shining example when dealing with the bloody-mindedness of their own governments.

Australia slipped two places to 21 st in 2019 as it continued to decline on the RSF World Press Freedom Index, which declared that while the country had good public media, the concentration of commercial media ownership had worsened since Channel Nine Entertainment took over the Fairfax media group and put investigative journalism at risk (RSF, 2019a). The following year, 2020, it declined further to 26th place, with the RSF noting the 'fragility' of journalistic freedom in the Commonwealth and the lack of a constitutional guarantee of press freedom (RSF, 2020).

The criticisms were echoed by the independent Sydney website Crikey!, which has been describing Australia as a police state for some time. In an article headlined 'Welcome to Stasiland Down Under', a reference to the methods of the East German secret police, the Stasi, the website warned about the legal risks for Australian media outlets using footage sourced from foreign broadcasters - even potentially those in the Pacific (Keane, 2019).

The independent Criminal Lawyers website also warned about proposed new laws about to be introduced by the Attorney-General's Office to target 
environment groups and climate change activists (Gregoire, 2019). The website cited the actual words describing the draft law by Prime Minister Scott Morrison addressing a 'room full of his fossil fuel mates'. Morrison called the draft law:

Apocalyptic in tone. It brooks no compromise. It's all or nothing. Alternative views are not permitted. (Gregoire, 2019)

This raises the question of climate change and media freedom on Melanesia. One of the questions that I was asked by a group of Indonesian communication studies students in Yogyakarta in November 2019 was when Greta Thunberg, the young Swedish teenager championing climate change activism, faced abuse and ridicule by some global politicians. The students asked what they should do. I replied, 'Do something. It is your future. Don't rely on dinosaur politicians who don't have the answers and don't have the sense of urgency needed to tackle climate change.'

I was heartened by reports in September that four Pacific Islands children were among the 16 youth, including Thunberg, who filed a complaint on the climate crisis to the United Nations. Their petition to the UN Committee on the Rights of the Child (CRC) was a bold attempt to hold Argentina, Brazil, France, Germany and Turkey accountable for their alleged climate crisis inaction. This was the first time children had petitioned the UNCRC. The Pacific students were Carlos Manuel, a 17-year-old from Palau (and originally from the Philippines), and three Marshall Islanders-Litokne Kabua, David Ackley II and Ranton Anjain. They addressed the US in their indigenous languages.

In contrast to this youthful clarity and courage, the Pacific's case for global support on the climate crisis suffered a serious blow when it was formally announced in early November that the United States was withdrawing from the Paris Accord on climate change (RNZ, 2019f). Although President Donald Trump had long signalled this arrogant and short-sighted move, the formal notification of the one-year withdrawal process was met with dismay around the world.

Pacific Islands Forum chair Kausea Natano, who is also Prime Minister of Tuvalu, one of the Pacific climate crisis frontline states, said the withdrawal would undermine US influence and credibility in the Pacific - just when there was a growing concern in Western countries about Chinese influence in the region (RNZ, 2019g). He said Washington used to play a leadership role in supporting multilateralism and promoting a global rules-based system. However, the Forum chair argued that it was disappointing to see the ethos 'fade and falter' when it was so vitally needed in the world.

This focuses on the challenge for Melanesian and Pacific journalists- how to promote the Pacific agenda on climate crisis. The world's media must accept that we are long past the era of deniability. It is now time for action and time is running out. 
The Forum's Kainaki II Declaration for Urgent Climate Action Now (Kainaki II, 2019) that the shared prosperity of the 'Blue Pacific' continent could only safely exist if the international community pursues efforts to limit warming to 1.5 deg Celsius, as stated in the Paris climate agreement, is a laudable objective. Scientists of the Intergovernmental Panel on Climate Change (IPCC), a UN body, have been warning since 1988 that human activity, industrialisation and the world's dependence on fossil fuels have caused the warming of global temperatures that threaten life on Earth. By contrast, climate change deniers dismiss such dire premonitions as conspiracy.

I wrote in a new 2019 book for Asia-Pacific journalists, Science Writing and Climate Change, that:

This is a challenge for journalists and the media who need to counter misinformation and ignorance. While there is a reported 97 percent scientific consensus about the cause of climate change, still some media organisations, such as those owned by billionaire Rupert Murdoch in Australia and the United States, give disproportionate oxygen to deniers. (Robie, 2019b, p. iii)

The lead author of this book, Professor Crispin Maslog of the Philippines, notes there are not enough qualified or trained journalists in the Asia-Pacific region who have the insights and expertise to report and analyse with enough depth and are yet able to connect with ordinary people. He wrote:

Local media is largely confined to traditional disaster reporting of casualties, physical destruction and damage to property, as it should be. But there is little contextual reporting and explanation of why these natural disasters are happening more often and more violently. (Maslog, 2019, p. 2)

The good news is that in contrast to Australia, the New Zealand Parliament has passed landmark legislation that enshrines the national commitment to the Paris Accord into law, and will hopefully see the country achieve zero net carbon dioxide emissions by 2050 (Mazengarb, 2019). The new law will establish New Zealand as one of the few countries in the world with a legislated commitment to establishing policies consistent with limiting global warming to just $1.5 \mathrm{deg}$. Celsius. It was passed with almost unanimous bipartisan support, including the conservative National Party.

\section{West Papua - 'black hole' in the Pacific}

Finally, to West Papua. West Papua has generally been poorly covered by New Zealand's mainstream media, apart from RNZ Pacific, and a handful of specialist websites such as the Pacific Media Centre's Asia Pacific Report. The situation 
is only slightly better in Australia. Papua has generally been regarded as a media 'black hole' or 'black spot' (Andrew, 2019; Leadbeater, 2018; RNZ, 2018; Robie, 2014, 2017b, 2019a, 2019b; Webb-Gannon, 2019). When Camellia Webb-Gannon wrote in October 2019 about the experience of bringing West Papuan survivors of the little-known 1998 Biak massacre to give evidence before a citizens tribunal at the University of Sydney in 2013, she recalled:

Singing and creating the combined testimony became, for the participating survivors, acts of healing, of ensuring the restrained legal procedure of the tribunal also privileged Papuan culture and foregrounded Papuan agency and voices.

Realising the importance of art—in particular, music — in West Papua's decolonisation movement, members of the Tribunal's organising group were inspired to apply for a research grant to explore how art could be further used to facilitate social justice in similar instances. (Webb-Gannon, 2019)

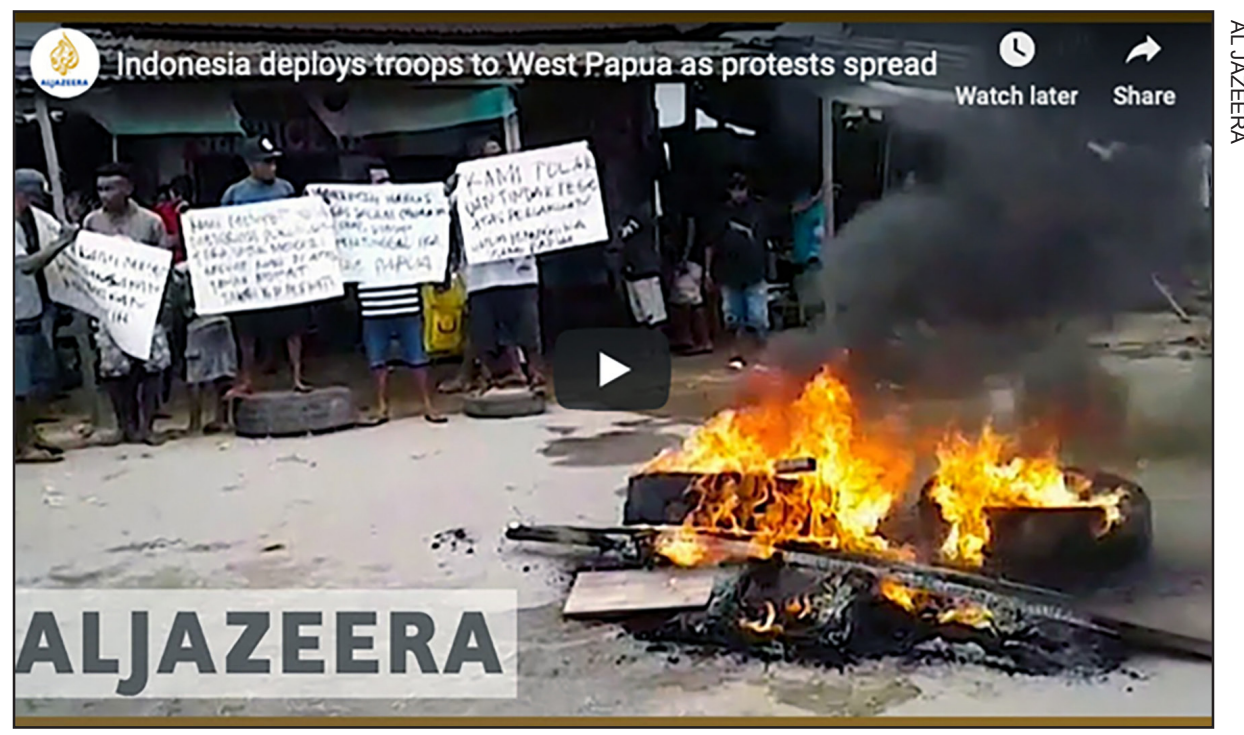

Figure 3: Al Jazeera reports on the protests and rioting in Papua in response to a racist attack in Surabaya, Java, 22 August 2019.

The recent turmoil has included (Figure 3):

December 2018: Papuan resistance fighters killed 19 Indonesian construction workers employed on the Trans-Papua Highway at Nduga, in Papua province. However, the status of the workers has been in dispute as resistance leaders have claimed they were in fact soldiers (Mambor, 2019).

January 2019: One Indonesian soldier was killed in Nduga. 
March 2019: Three more soldiers were killed in Nduga.

July 22, 2019: Solidarity Team for Nduga aid agency reported 139 people had died in displacement camps in the previous six months and 5000 people had been displaced by the conflict (RNZ, 2019a).

August/September 2019: The violence worsened with a police officer being shot dead on August 12, and a soldier dying after a Papuan resistance ambush. Between August 19 and late September, huge demonstrations broke out calling for independence after Indonesian students were reported to have racially insulted Papuans studying in Surabaya and Malang (Figure 4). The rallies erupted in Fak-Fak, Jayapura, Manokwari, Sorong, and also in the capital of Jakarta. Demonstrators torched several buildings including the local parliament in Manokwari, capital of West Papua province (Doherty, 2019; Firdaus, 2019a).

The Widodo administration - led by the very president who had grandstanded a new 'open era' (The Guardian, 2015) for Papua when first elected in 2014 and who has now backtracked on his promises after winning a new five-year term in 2019-was quick to blame the United Liberation Movement for West Papua (ULMWP) and its exiled leader, London-based Benny Wenda, for the demonstrations and violence (Blades \& Smith, 2019). A fresh round of arrests began and harassment of rights lawyers defending the protesters, such as Veronica Koman (Pacific Media Watch, 2019c; RNZ, 2019b). It was a delight to see that in October Veronica had been awarded the Sir Ronald Wilson Human Rights Award while she was living in Australia, away from the Indonesian threats and an arrest attempt through Interpol (Asia Pacific Report, 2019).

More recently, in April 2020, Veronica Koman teamed up with Jennifer Robinson and the Indonesian human rights watchdog TAPOL (2020) to represent 63 political prisoners detained on treason charges in making a joint urgent appeal to the UN Working Group on Arbitrary Detention and UN Special Rapporteurs in response to the global coronavirus pandemic. The prisoners were 56 indigenous West Papuans, five Moluccans, one Indonesian, and one Polish citizen. They had all been charged with makar (treason), a crime that carries punishment of up to 20 years in jail.

In an Asia Pacific Report commentary, I warned that Indonesia would ignore the lessons of Timor-Leste at its peril as the stakes grew higher for West Papua (Leadbeater, 2007; Robie, 2014). I added:

Indonesia's harsh policies towards West Papua ought to be scrapped. Whatever happened to the brief window of enlightenment ushered in by President Joko 'Jokowi' Widodo in 2015 with promises of a more 'open door' policy towards foreign journalists and human rights groups?

They were supposed to be seeing for themselves the reality on the 


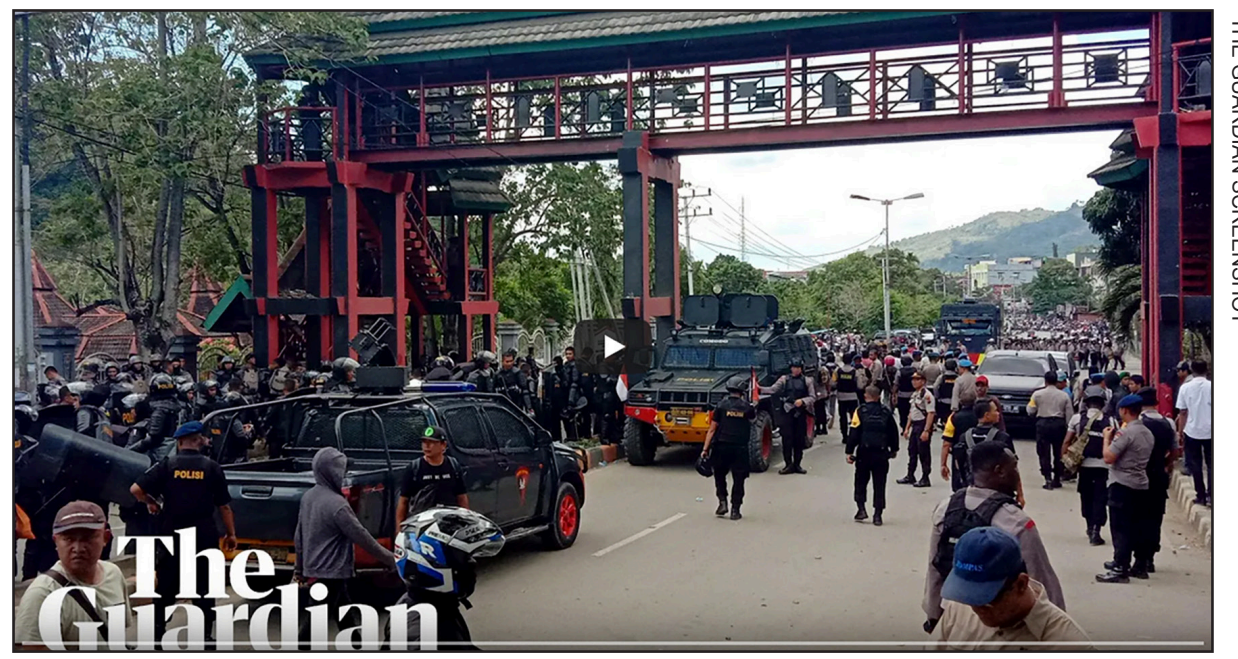

Figure 4: Guardian footage from citizen journalists in West Papua, 23 September 2019.

ground. But apart from a trickle of carefully managed visits by selected journalists after the grand announcement-including two multimedia crews from RNZ Pacific and Māori Television in 2015 - no change really happened. The serious media freedom and human rights violations remain rampant. (Blades, 2016; Robie, 2019c; RSF, 2019a)

Indonesia's bureaucrats and government are tenacious about imposing obstacles on foreign media access to Papua (Figure 5). There is a routine perception and 'suspicion that the presence of foreign media and human rights activists in East Timor helped pave the way to that former Indonesian [occupied] province's independence in 2002' (Kline, 2016). The extent of blacklisting and repression against journalists by Indonesian authorities was superbly outlined by Australian investigative journalist John Martinkus in his 2020 book The Road: Uprising in West Papua. He concludes: 'No amount of hiding the truth can stop the reality of the situation in Papua coming to light ... [I]f the Indonesians and the Australians and the UN continue their current policies in Papua, there will never be peace (Martinkus, 2020, p. 109).

In the wake of the protests and shootings, reports revealed that Indonesia had blocked foreign diplomats from visiting West Papua, with British, Canadian and New Zealand officials denied entry (RNZ, 2019d). Intolerable pressure was put on West Papuan journalists by Indonesian police and security forces and a well-funded social media campaign was launched by using 'bots' to promote the pro-government agenda (Pacific Media Watch, 2019b; RNZ, 2019c, 2019e). An investigation by BBC News and the Australian Policy Institute (ASPI) revealed that a flood of easily recognisable 'bots' — or automated fake accounts - would 


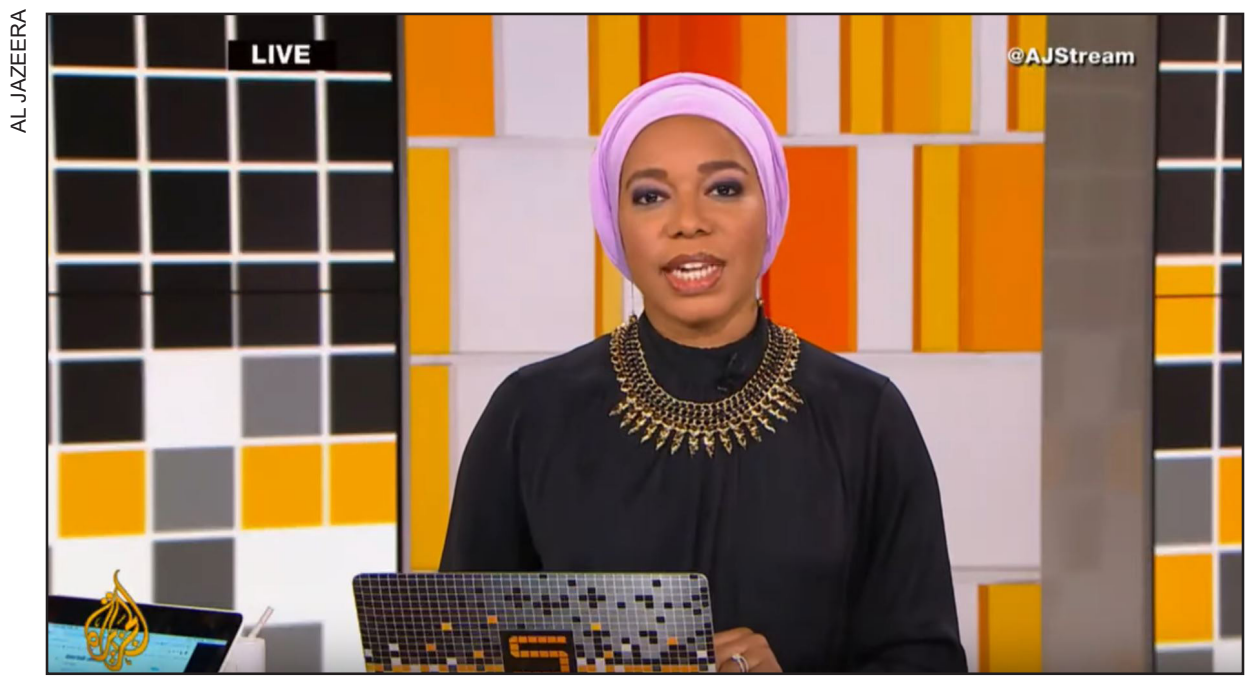

Figure 5: Should West Papua remain part of Indonesia? The Stream, 6 September 2019.

piggyback on hashtags supporting independence, such as \#freewestpapua and drown out negative news (Strick \& Syavira, 2019).

Reports at the end of September revealed how police were stifling reporting by local journalists. Before the protests peaked, police reportedly blocked three reporters working for The Jakarta Post (Benny Mawel), Suara Papua (Ardi Bayage) and Tabloid Jubi (Hengky Yeimo) from covering student demonstrations. This echoed earlier research by Tabloid Jubi's Victor Mambor, long an advocate for a free media in West Papua, who had lodged a United Nations appeal with support by human rights lawyers to lift the Indonesian internet ban during August (Pacific Media Watch, 2019a).

In June, a document was presented to Britain's House of Commons Foreign Affairs Committee alleging a range of human rights violations. Prepared by researcher Pelagio Da Costa Sarmento of TAPOL and Tabloid Jubi's Mambor, the submission was a response to an inquiry by the Commons Select Committee into the Foreign and Commonwealth Office (FCO) and Global Media Freedom in an effort to combat disinformation.

A covering declaration accompanying the submission made it clear the report was exposing the current state of lack of media freedom in West Papua.

Over the last 10 years, journalists and news organisations have faced serious threats to their personal security, as well as being targeted by digital disinformation campaigns that aimed to disrupt the work of legitimate news sources and reporting.

"The death of two local journalists, assaults on multiple others and several cases of international journalists being deported from Indonesia 
for reporting on or in West Papua underscores the lack of media freedom of West Papua. (Sarmento \& Mambor, 2019)

In a commentary about Sarmento and Mambor's submission to the House of Commons and in response to a renewed 'charm offensive' diplomacy in the Pacific by Indonesia in Asia Pacific Report, I wrote:

Indonesia recently hosted a bold public relations window-dressing expo in Auckland presenting itself as a 'Pacific' nation while attempting to provide an unconvincing impression of normality in the two Melanesian provinces...

Indonesian Foreign Minister Retno Marsudi hailed 'a new era of Pacific partnership - a Pacific Elevation' while New Zealand's counterpart, Winston Peters, responded to human rights questions with a remarkably naïve statement that Indonesia was 'making progress' by welcoming a press pack to West Papua.

Nothing could be further from the truth. Papuan critics have dismissed this Pacific Expo as effectively 'fake news' - a cover-up of more than a half-century of repression and distortion. (Robie, 2019c)

I first encountered Victor Mambo when he became the first Papuan journalist to visit New Zealand in 2013 and I subsequently shared with him in a Melanesian parallel people's panel during the UNESCO World Press Freedom Summit in Jakarta in May 2017 (Robie, 2017a, 2017b).

\section{The PMC and human rights journalism}

This brings me to the contribution of the Pacific Media Centre in the Melanesian media freedom debate. While Victor was in Auckland, my students were involved in an indigenous Māori welcoming powhiri and seminar for him as a 'political teach-in'. Many of the students did interviews and wrote stories. As part of that exercise, a video report entitled Media 'Freedom' in West Papua Exposed (Figure 6) was made by student journalist Struan Purdie (Pacific Media Centre, 2014):

The PMC — or Te Amokura — was founded in AUT's School of Communication Studies in 2007 as a research and publication unit and is probably unique in a university environment, certainly in New Zealand (http://pmc.aut.ac.nz). The initiative came out of my Design and Creative Technologies faculty in response to an evolving pool of Pacific journalism research and publication, including this journal, Pacific Journalism Review (https://ojs.aut.ac.nz/pacific-journalism-review/), launched at the University of Papua New Guinea in 1994. The centre now also publishes three news and current affairs websites-Asia Pacific Report (general Asia-Pacific news), Pacific Media Centre Online (specialist media reports and 


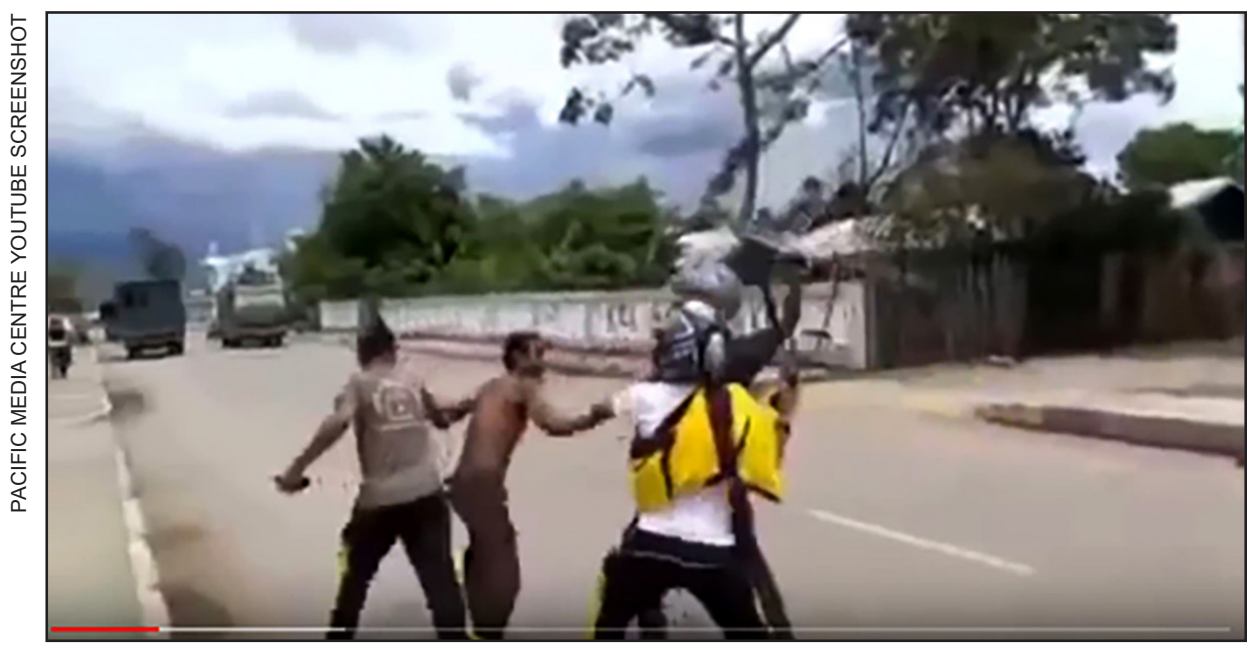

Figure 6: Media 'Freedom' in West Papua Exposed, student journalist report.

research) and Pacific Media Watch (regional media monitoring), Pacific Journalism Monographs research publications and a range of books. All the books and publications are available via AUT Shop (www.autshop.ac.nz/pacific-media-centre/). The mission is:

Informed journalism and media research contributes to economic, political and social development and the Pacific Media Centre-Te Amokuraseeks to stimulate research into contemporary Māori, Pasifika and ethnic diversity media and culture production (About the Pacific Media Centre https://pmc.aut.ac.nz/content/about-pacific-media-centre).

A core of our teaching and philosophy of media is focused on human rights journalism. One of the more enlightened advocates for human rights journalism (HRJ) is global justice and former Sierra Leone newspaper editor Ibrahim Seaga Shaw. He points out that traditional human rights journalism has either been seen through the prism of the journalist reporting on human rights abuses, or on free speech, which is itself a 'human right'. However, he says those approaches do not go far enough.

Shaw is co-author of an excellent book on peace journalism, including HRJ, entitled Expanding Peace Journalism. Jason MacLeod's book on peaceful protest by West Papuans over the past decade leading up to the renewed conflict in the past 18 months, Merdeka and the Morning Star, is also an essential read in this context. My own 2014 Pacific book, Don't Spoil My Beautiful Face, presents a persuasive case for human rights journalism in Melanesia and the Pacific.

In his book, Shaw argues that 'mainstream minority-world journalism generally sides with official rhetoric and policy stances of the governments in the 
countries in which it is produced' (Shaw, 2011, p. 97). Hence West Papua and human rights are underreported in Australia and New Zealand, if not in Pacific countries. Where human rights violations are reported, they are usually portrayed as 'the actions of individual perpetrators, not as the product of a system and of structures that construct and sustain long-term relations in conflict'. According to Jake Lynch, the 'predominant war journalism of conflict reporting in the wealthy northern hemisphere also dominates global news flows' (Lynch, 2008, p. 79). Shaw adds:

Mainstream journalism has failed to communicate not only peace, but also human rights in ways that have the potential of illuminating the important nexus between them. Perhaps more importantly, mainstream journalism has failed to focus on the potential for positive peacebuilding and on positive human rights to match the dominant negative peace negative rights emphasised within the cosmopolitan context of global justice. (Shaw, 2011, p. 98)

Much research has also highlighted the 'economic injustice' imposed by Indonesia and the region's extractive industries in the two Melanesian provinces when the Papuan people remain among the poorest of the communities in Indonesia. As a National University of Singapore researcher argues,

Papua's resources are plundered by foreign countries such as PT Freeport McMoran [now with Indonesian majority shareholding in the US established company], which owns the world's largest gold mine of the territory. Massive environmental degradation is also a sore point among the Papuans, who view their forests as sacred communal lands. (Singh, B., 2019)

Many regional companies are complicit in this exploitation. In 2011, Metro magazine, a leading New Zealand glossy magazine reporting issues and society, published an investigation, entitled 'Blood Money', probing the NZ Superannuation Fund's (NZSF) investment in the Freeport mine. It led to awards for the investigative journalist, Karen Abplanalp, then a postgraduate student at Auckland University of Technology, and also ultimately forced the fund to abandon the 'unethical' investment (Abplanalp, 2012).

This student also carried out excellent research about media coverage of West Papua in the Asia-Pacific region. She interviewed a range of journalists in Australia, Indonesia and New Zealand and created a research website with their video statements. Her website was embargoed for a few years, but it is now available on the university research repository. Meanwhile, a collaborative research project seeking to map the extent of Indonesian human rights violations since the takeover of the Melanesian region has got under way as part of wider research across the archipelago (Webb-Gannon, Swift, Westaway \& Wright, 2020). 
This article has overwhelmingly dealt with the West Papuan crisis because this is the major one challenging Melanesia and the Pacific in the region at present. In fact, if Australia and New Zealand do not rethink their Papuan strategy —or rather, lack of one - and strongly side with the Pacific bloc, led by Vanuatu, in unambiguously supporting Papuan self-determination, then the region faces growing insecurity.

\section{Conclusion}

However, there are also other major media issues confronting Melanesia. Serious problems stifling media freedom - and probably ultimately a graver threat than repression by governments - is dwindling resources in many newsrooms, especially for investigative journalism; and a culture of subservience to the 'big man' syndrome. Crackdowns on social media, such as in Fiji, Papua New Guinea and Samoa are also a serious threat.

Those journalists who do stick their necks out in defence of a free press or investigating corruption ought to be lauded - it takes real cocurage to do so in the Pacific. I am singling out EMTV's Scott Waide, Neville Choi and Sincha Dimara; the Vanuatu Daily Post's Dan McGarry, Fiji's Simpson@Eight-he is doing an exemplary job on a University of the South Pacific management exposé at present - and Alex Rheeney and Mata'afa Keni Lesa at the Samoa Observer as examples. However, there are many more who deserve credit.

Writing in September 2019 in Scott Waide's blog, My Land, My Country, in a column to mark Papua New Guinea's 44th independence anniversary, Lucy Kopana made a disparaging comparison with the West Papuan struggle. She noted: 'Many countries fought blood, tooth and nail to gain independence from their colonisers. Papua New Guinea did not.' In the piece subtitled 'West Papua: The Melanesian country in waiting', she wrote:

West Papua is not just a neighbouring country; they are part of the Melanesian family. We share more than a border; we share a land mass divided by an invisible line set by the colonial countries that governed us. In the colonisers' efforts to gain territories for their countries, they divided families, clans, cultures and ethnicities. They divided WAN PIPOL. People that shared the same dark skin and fuzzy hair. (Kopana, 2019)

The big question that faces us as independent journalists in the Pacific is what do we do about this crisis given the spineless response of many governments in our region. Here is my wish list if we take a human rights approach to the issue: Journalists in the Pacific should press Indonesia for:

1. An impartial investigation into the cases of arbitrary arrest and impunity in West Papua, as well as other places in the Republic; 
2. A guaranteed right to freedom of expression, freedom of association and assembly for all Papuans;

3. Open access to West Papua for the international community, including journalists, diplomats and NGO advocates;

4. An early date for the projected visit of the UN Special Rapporteur on Freedom of Expression; and

5. A new United Nations-administered independent plebiscite for the future of West Papua

Thanks to the courage of Tabloid Jubi's Victor Mambor, we had the opportunity to debate these issues publicly in a ground-breaking webinar with a senior Indonesian Foreign Affairs official which became rather strained over discussion of 'self-determination' and justice for Papuans (PMW, 2020).

Kia ora. Kia mihi. Papua merdeka.

\section{Web resources}

AUT Shop-Pacific Media Centre publications: www.autshop.ac.nz/pacific-media-centre/ Asia Pacific Report: https://asiapacificreport.nz/

Pacific Media Centre Online: https://pmc.aut.ac.nz/

Pacific Media Watch: www.pacmediawatch.aut.ac.nz

Pacific Media Centre on Facebook: www.facebook.com/PacificMediaCentre/

\section{References}

About the Pacific Media Centre (n.d.). Pacific Media Centre Online. Retrieved on October 19, 2019, from https://pmc.aut.ac.nz/content/about-pacific-media-centre

Abplanalp, K. (2012). FRONTLINE: 'Blood Money': A NZ investigative journalism case study. Pacific Journalism Review : Te Koakoa, 18(1), 128-147. https://doi. org/10.24135/pjr.v18i1.293

Abplanalp, K. (2015). Media restrictions on Papua - understanding the impacts. Master of Communication Studies exegesis/microsite project, Pacific Media Centre, Auckland University of Technology. [Microsite]. https://openrepository.aut.ac.nz/handle/10292/9649

Al Jazeera (2019, August 21). Indonesia deploys troops to West Papua as protests spread. [Video]. Retrieved on October 19, 2019, from https://www.youtube.com/ watch? $\mathrm{v}=13 \mathrm{~Gb} 7 \mathrm{DGW} 2 \mathrm{Y}$

Al Jazeera (2019, September 6). Should West Papua remain part of Indonesia. The Stream. [Video]. Available at https://www.youtube.com/watch?v=E71HPCCbLkA

Andrew, M. (2019, September 11). On the NZ media's coverage of West Papua. Asia Pacific Report. Retrieved on October 19, 2019, from https://asiapacificreport. nz/2019/09/11/michael-andrew-the-nz-medias-coverage-of-the-west-papua-protest/ Asia Pacific Report (2019, October 24). Veronica Koman wins prize for West Papua work. Retrieved on October 19, 2019, from https://asiapacificreport.nz/2019/10/24/ veronica-koman-wins-prize-for-west-papua-work/ 
Blades, J. (2016). Watching this space, West Papua. Pacific Journalism Review: Te Koakoa, 22(1), 13-24. https://doi.org/10.24135/pjr.v22i1.10

Blades, J., \& Smith, M. (2019, September 6). Jakarta blames Papua unrest on independence movement. Retrieved on 19 October, 2019, from https://www.rnz.co.nz/international/pacific-news/398273/jakarta-blames-papua-unrest-on-independence-movement Clooney, A. (2019, July 11). Amal Clooney criticises raid on ABC newsroom in Sydney [Video]. The Guardian. Retrieved on October 19, 2019, from https://www.theguardian.com/world/video/2019/jul/11/amal-clooney-criticises-raid-on-abc-newsroomin-sydney-video

Davidson, H. (2019, November 8). 'Attack on the media': Vanuatu newspaper boss has work visa refused. The Guardian. Retrieved on November 9, 2019, from https://www. theguardian.com/world/2019/nov/08/attack-on-the-media-vanuatu-newspaper-bosshas-work-visa-refused

Doherty, B. (2019, August 19). Protesters set fire to parliament building in West Papua as tensions mount. The Guardian. Retrieved on October 19, 2019, from https://www. theguardian.com/world/2019/aug/19/protesters-set-fire-to-parliament-building-inwest-papua-as-tensions-mount

Doran, M. (2019, October 21). Media unites to rally for press freedom, taking campaign to front pages and airwaves. ABC News. Retrieved on Nivember 9, 2019, from https:// www.abc.net.au/news/2019-10-21/media-unites-to-rally-for-press-freedom/11621806

Firdaus, F. (2019a, August 19). Fiery protests erupt in Indonesia's West Papua region. Al Jazeera English. Retrieved on October 19, 2019, from https://www.aljazeera.com/ news/2019/08/fiery-protests-erupt-indonesia-west-papua-region-190819031537473. html

Firdaus, F. (2019b, August 23). Indonesia blocks internet as West Papua as protests rage. Al Jazeera English. Retrieved on October, 19, 2019, from https://www. aljazeera.com/news/2019/08/indonesia-blocks-internet-west-papua-protest-rages-190822022809234.html

Goodman, R. S., \& Steyn, E. (2017). Global journalism education in the $21^{\text {st }}$ century: Challenges and innovations. Austin, TX: Knight Center for Journalism in the Americas.

Gregoire, P. (2019, November 11). Morrison intensifies campaign to silence Australians. Sydney Criminal Lawyers. Retrieved on November 12, 2019, from https://www.sydneycriminallawyers.com.au/blog/morrison-intensifies-campaign-to-silence-australians/

Harsono, A. (2019). Race, Islam and power: Ethnic and religious violence in post-Suharto Indonesia. Melbourne: Monash University Publishing.

Kainaki II (2019). Fiftieth Pacific Islands Forum, Funafuti, Tuvalu, communiqué and Kainaki II declaration for urgent climate change action now. Suva: Pacific Islands Forum Secretariat. Retrieved on October 19, 2019, from https://www.forumsec.org/ wp-content/uploads/2019/08/50th-Pacific-Islands-Forum-Communique.pdf

Keane, B. (2019, November 6). Welcome to Stasiland down under. Crikey! Retrieved on November 9, 2019, from https://www.crikey.com.au/2019/11/06/attorney-generalsdepartment-stasiland/

Kline, P. (2016, January 22). Indonesia's Papua reporting paranoia: Despite Widodo's promise of an 'opening', journalists are still being kept out of Papua. The Diplomat. Retrieved on October 19, 2019, from https://thediplomat.com/2016/01/indonesiaspapua-reporting-paranoia/

Kopana, L. (2019, September 2). West Papua and Papua New Guinea: Two distinct realities, one people. My Land, My Country. [Blog]. Retrieved on October 19, 2019, from https://mylandmycountry.wordpress.com/2019/09/02/west-papua-papua-new- 
guinea-two-distinct-realities-one-people/

Krishnamurthi, S. (2019, November 9). Vanuatu Daily Post's Dan McGarry 'gutted' by Vanuatu government's action to reject his work permit. Asia Pacific Report. Retrieved on November 9, 2019, from https://asiapacificreport.nz/2019/11/09/vanuatu-dailyposts-dan-mcgarry-gutted-by-vanuatu-governments-action-to-reject-his-work-permit/

Leadbeater, M. (2007). Negligent neighbour: New Zealand's complicity in the invsion and occupation of Timor-Leste. Nelson: Craig Potton.

Leadbeater, M. (2018). See no evil: New Zealand's betrayal of the people of West Papua. Dunedin: Otago University Press.

Lynch, J. (2008). Debates in peace journalism. Sydney: Sydney University Press.

Lyons, K., \& Meade, A. (2019, October 30). 60 Minutes reporter Liam Bartlett and TV crew detained in Kiribati. Retrieved on November 9, 2019, from https://www. theguardian.com/world/2019/oct/30/60-minutes-reporter-liam-bartlett-and-crewdetained-in-kiribati

Macleod, J. (2015). Merdeka and the Morning Star: Civil resistance in West Papua. St Lucia, Qld: University of Queensland Press.

McGarry, D. (2019a, July 6). Six Chinese deported. Vanuatu Daily Post. Retrieved on October 19, 2019, from https://dailypost.vu/news/six-chinese-deported/ article 1016b6a7-2a6e-5c21-84b8-6f97928bd384.html

McGarry, D. (2019b, November 8). Statement. Dan McGarry Facebook. Retrieved on November 9, 2019, from https://www.facebook.com/dan.mcgarry.3705

McGarry, D. (2019c, November 10). Vanuatu has cancelled my work permit; it's a dark day for media freedom. The Guardian. Retrieved on November 11, 2019, from https:// www.theguardian.com/world/commentisfree/2019/nov/11/vanuatu-has-cancelled-mywork-permit-its-a-dark-day-for-media-freedom

Mambor, V. (2019, March 10). Asia Pacific Report. Retrieved on October 19, 2019, from https://asiapacificreport.nz/2019/03/10/papuan-residents-fearful-as-indonesianmilitary-buildup-still-grows/

Martinkus, J. (2020). The road: Uprising in West Papua. Carlton, Vic: Black Books.

Maslog, C. (2019). Climate change and media reporting. In C. Maslog, D. Robie, and J. Adriano (Eds.), Science writing and climate change. Manila: Asian Institute of Journalism and Communication.

Mayron, S. (2019, September 24). Pacific children file climate crisis complaint to the United Nations. Samoa Observer. Retrieved on October 19, 2019, from http://www. samoaobserver.ws

Mazengarb, M. (2019, November 8). New Zealand passes historic zero carbon bill with near unanimous bipartisan support. Renew Economy. Retrieved on November 9, 2019, from https://reneweconomy.com.au/new-zealand-passes-historic-zero-carbon-billwith-near-unanimous-bipartisan-support-33500/

MMFF (Melanesia Media Freedom Forum) (2019). Melanesia Media Freedom Forum: Who are we? Retrieved on October 19, 2019, from https://www.griffith.edu.au/learning-futures/service-learning/events-and-innovation/melanesian-media-freedom-forum

Nantara, A. (2019, November 6). 'I don't like being challenged': Premier Gina threatens to close down Island Sun office in Gizo, The Island Sun News. Retrieved on November 9 , 2019, from https://www.facebook.com/theIslandSunNews/posts/2327048520958993

Pacific Media Centre (2014, August 10). Media 'freedom' in West Papua exposed. [Video]. https://www.youtube.com/watch?v=yvFSCJXsgqM

PMW (Pacific Media Watch) (2019a, August 20). PNG: EMTV staff protest over sacking of 'flawless' news manager Neville Choi. Pacific Media Watch on Asia Pacific 
Report. Retrieved on October 19, 2019, from https://asiapacificreport.nz/2019/08/20/ emtv-staff-protest-over-sacking-of-flawless-news-manager-neville-choi/

PMW (Pacific Media Watch) (2019b, August 26). WEST PAPUA: Papua free media advocate files UN 'blackout' plea, targeted by hacker. Asia Pacific Report. Retrieved on October 19, 2019, from https://asiapacificreport.nz/2019/08/26/papua-free-mediaadvocate-files-un-blackout-plea-targeted-by-hacker/

PMW (Pacific Media Watch) (2019c, September 27). WEST PAPUA: Intimidation of journalists condemned. Retrieved on October 19, 2019, from https://pmc.aut.ac.nz/ pacific-media-watch/west-papua-intimidation-journos-condemned-10534

PMW (Pacific Media Watch) (2019d, October 4). WEST PAPUA: Veronica Koman 'won't be silenced' despite daily death threats. Retrieved on October 19, 2019, from https://pmc.aut.ac.nz/pacific-media-watch/west-papua-veronica-koman-wont-besilenced-despite-daily-death-threats-10538

PMW (Pacific Media Watch). (2020, July 3). Webinar panel on West Papua sharply divided over media black hole, Asia Pacific Report. Retrieved on July 11, 2010, from https://asiapacificreport.nz/2020/07/03/webinar-panel-on-papua-sharply-dividedover-media-black-hole/

Raza, T. (2019). Mapping digital disinformation around elections: A case study of Pakistan's 2018 general elections. CIMA Digital Report. Retrieved on November 9, 2019, from https:/www.cima.ned.org/publication/mapping-online-disinformationaround-pakistans-2018-general-elections/

RNZ (Radio New Zealand). (2018, July 4). West Papua a 'black hole' for human rights. Dateline Pacific. Retrieved on October 19, 2019, from https://www.rnz.co.nz/international/programmes/datelinepacific/audio/2018652035/west-papua-a-black-holefor-human-rights

RNZ (2019a, July 22). At least 139 dead in Papuan displacement camps - aid group. Retrieved on October 19, 2019, from https://www.rnz.co.nz/international/pacificnews/394788/at-least-139-dead-in-papuan-displacement-camps-aid-group

RNZ (2019b, September 5). Indonesian lawyer targeted for Papua incitement. Retrieved on October 19, 2019, from https://www.rnz.co.nz/international/pacific-news/398172/ indonesian-lawyer-targeted-for-west-papua-incitement

RNZ (2019c, September 26). Intimidation of journos in Papua condemned. Retrieved on October 19, 2019 from https://www.rnz.co.nz/international/pacific-news/399662/ intimidation-of-journos-in-papua-condemned

RNZ (2019d, October 9). Indonesia blocks diplomats from West Papua - media report. Retrieved on October 19, 2019, from https:/www.rnz.co.nz/international/pacificnews/400601/indonesia-blocks-diplomats-from-west-papua-media-report

RNZ (2019e, October 11). Papua unrest : Social media bots 'skewing the narrative'. Retrieved on October 19, 2019, from https:/www.rnz.co.nz/news/world/400776/ papua-unrest-social-media-bots-skewing-the-narrative

RNZ (2019f, November 5). Paris climate accords: US notifies UN of intention to withdraw. Retrieved on November 9, 2019, from https:/www.rnz.co.nz/news/ world/402618/paris-climate-accords-us-notifies-un-of-intention-to-withdraw

RNZ (2019g, November 11). US will lose Pacific influence over Paris decision - forum. Retrieved on November 12, 2019, from https:/www.rnz.co.nz/international/pacificnews/402721/us-will-lose-pacific-influence-over-paris-decision-forum

Robie, D. (2014). Don't spoil my beautiful face: Media, mayhem and human rights in the Pacific. Auckland: Little Island Press.

Robie, D. (2017a). Indonesian double standards over press freedom endanger safety of 
Papuan journalists. Media Asia, 44(1), 40-47. https://www.tandfonline.com/doi/abs /10.1080/01296612.2017.1379812

Robie, D. (2017b). Tanah Papua, Asia-Pacific news blind spots and citizen media: From the 'Act of Free Choice' betrayal to a social media revolution. Pacific Journalism Review : Te Koakoa, 23(2), 159-178. https://doi.org/10.24135/pjr.v23i2.334

Robie, D. (2019a, May 3). Pacific countries score well in media freedom index, but reality is far worse. The Conversation. https://theconversation.com/pacific-countries-scorewell-in-media-freedom-index-but-reality-is-far-worse- 116373

Robie, D. (2019b). Running out of time. In C. Maslog, D. Robie \& J. Adriano (Eds.), Science writing and climate change (pp. 1-4). Manila: Asian Institute of Journalism and Communication.

Robie, D. (2019c, July 22). Indonesia's cover up over Papuan media freedom violations exposed. Asia Pacific Report. Retrieved on October 19, 2019, from https:// asiapacificreport.nz/2019/07/22/indonesias-cover-up-over-papuan-media-freedomviolations-exposed/

Robie, D. (2019d, August 24). West Papua's road to 'independence', following the Timorese lead? Asia Pacific Report. Retrieved on October 19, 2019, from https:// asiapacificreport.nz/2019/08/24/west-papuas-road-to-independence-following-thetimorese-lead/

Robinson, J. (2019, October 21). Press freedom under threat from national security law spree. The Sydney Morning Herald. Retrieved on October 23, 2019, from https:// www.smh.com.au/national/press-freedom-under-threat-from-national-security-lawspree-20191020-p532f8.html

RSF (2019a). Investigative journalism in danger. Retrieved on October 19, 2019, from https://rsf.org/en/australia

RSF (2019b). President's broken promises. RSF World Press Freedom Index 2019. Retrieved from October 19, 2019, from https://rsf.org/en/indonesia

Sarmento, C., \& Mambor, V. (2019). Written evidence from TAPOL and Jubi (GMF0032). Retrieved on October 19, 2019, from http://data.parliament.uk/writtenevidence/ committeeevidence.svc/evidencedocument/foreign-affairs-committee/the-fco-andglobal-media-freedom/written/102716.html

Shaw, I. S. (2011). 'Human rights journalism': a critical conceptual framework of a complementary strand of peace journalism. In I. S. Shaw, J. Lynch, \& R. Hackett (Eds.), Expanding peace journalism: Comparative and critical approaches. Sydney: Sydney University Press.

Singh, B. (2019, September 12). Why is West Papua in constant turmoil: The Indonesian territory has struggled for independence for more than 50 years. [Online]. The Diplomat. Retrieved on October 19, 2019, from https://thediplomat.com/2019/09/why-is-west-papua-in-constant-turmoil/

Singh, S. (2017, October 18). Shailendra Singh: How journalists can walk the Pacific climate change talk. Asia Pacific Report. Retrieved on October 19, 2019, from https:// asiapacificreport.nz/2017/10/18/shailendra-singh-how-journalists-can-walk-thepacific-climate-change-talk/

Strick, B., \& Syavira, F. (2019, October 11). Papua unrest : Social media bots 'skewing the narrative'. BBC News. Retrieved on October 19, 2019, from https://www.bbc. com/news/world-asia-49983667

TAPOL (2020, April 15). Urgent appeals filed with UN by 63 political prisoners in Indonesia amid the COVID-19 pandemic. Retrieved on 19 May, 2020, from https:// www.tapol.org/news/urgent-appeals-filed-un-63-political-prisoners-indonesia-amid- 
covid-19-pandemic

Tarai, J. (2019). Social media and Fiji's 2018 national election. Pacific Journalism Review : Te Koakoa, 25(1\&2), 52-64. https://doi.org/10.24135/pjr.v25i1 and2.476

The Guardian (2015, May 10). Indonesia releases five West Papuan political prisoners as president pledges reforms. Agence France-Presse. Retrieved on October 19, 2019, from https://www.theguardian.com/world/2015/may/10/joko-widodo-releases-fivewest-papuan-political-prisoners-and-pledges-reforms

The Guardian (2019, September 23). Indonesian security forces open fire at student rally in West Papua. [Video]. https://www.youtube.com/watch?v=pv3oFsYj0gI

Wasuka, E. (2019, October 31). 60 Minutes crew flies out of Kiribati after two-day 'house arrest' in hotel. ABC News. Retrieved on November 9, 2019, from https:/www.abc. net.au/news/2019-10-31/60-minutes-crew-leaves-kiribati-after-two-days-house-arrest/11657042

Webb-Gannon, C. (2019, October 1). How stories through art and music helps West Papua heal from decades of abuse. The Conversation. Retrieved on October 19, 2019, from https://theconversation.com/how-telling-stories-through-art-and-music-helps-westpapuans-heal-from-decades-of-abuse-124098

Webb-Gannon, C., Swift, J., Westaway, M., \& Wright, N. (2020, May 15). The Conversation. Retrieved on May 18, 2020, from https://theconversation.com/fight-for-freedomnew-research-to-map-violence-in-the-forgotten-conflict-in-west-papua-128058

DrDavid Robie is professor of journalism and director of the Pacific Media Centre at Auckland University of Technology. He is founding editor of Pacific Journalism Review, and also editor of Pacific Journalism Monographs and convenor of Pacific Media Watch. He has authored several books, including Blood on their Banner, Eyes of Fire and Don't Spoil My Beautiful Face: Media, Mayhem and Human Rights in the Pacific. This article is a composite paper drawn from his MMFF pre-conference address in Brisbane on 28 October 2019 and a Zoom keynote presentation from Yogyakarta, Indonesia, on the second day of the conference on 12 November 2019.

david.robie@aut.ac.nz 